\title{
Artisanal Fisheries in the Ndumo Area of the Lower Phongolo River Floodplain, South Africa
}

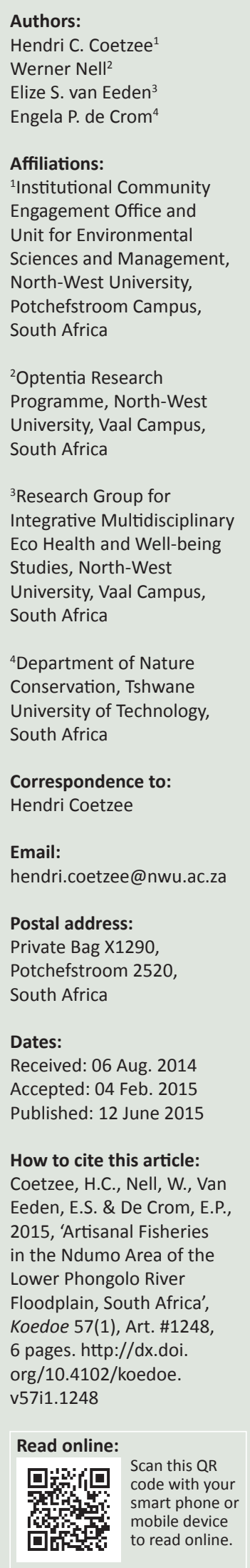

The aim of this study was to investigate the status of artisanal fisheries in the lower Phongolo River floodplain in northern KwaZulu-Natal, South Africa. A cross-sectional quantitative survey design was used that included the development of a questionnaire and a systematic survey among the five villages bordering the Ndumo Game Reserve. Data were collected over a 5-day period by a group of 16 fieldworkers and analysed using the Statistical Package for the Social Sciences, version 21. The results revealed that fish was the third most consumed protein in the area, that people consumed fish on average twice a week, that at least six fish species (and one recently introduced crayfish species) were consumed regularly, and that most fish were obtained from local vendors, who in turn bought it from local fishermen and -women. Fishing activities also appeared to occur predominantly along the river system and targeted mainly red-breasted tilapia (Tilapia rendalli) and Mozambique tilapia (Oreochromis mossambicus) and, to a slightly lesser extent, African sharptooth catfish (Clarias gariepinus) and brown squeaker (Synodontis zambezensis).

Conservation implications: Given that Ndumo residents predominantly catch fish by means of non-commercial methods, that they do so for reasons of personal consumption and subsistence, and that they mostly target rivers and dams rather than the ecologically sensitive pans in the region, it would seem likely that fishing in the region might be sustainable for the moment. However, it is recommended that studies on the local fish populations and their reproductive rates be conducted so that the actual impact on local fish populations can be determined more accurately. This study serves to provide the necessary baseline data on fish utilisation in the region, which would enable the impact of artisanal fishing on fish reserves in the Ndumo region to be determined once population studies have been completed.

\section{Introduction}

Artisanal or small-scale fisheries that support people's livelihoods are a worldwide phenomenon. They are characterised by the use of traditional fishing techniques, low-level technologies (e.g. handlines, rods, traditional boats, etc.) and normally take place close to the shore. The fish that are caught are intended mostly for local markets. Artisanal fisheries tend to have a much smaller impact on local fish populations compared to large-scale commercial fishing practices and thus tend to be more sustainable (Béné, Macfadyen \& Allison 2007).

Throughout central and southern Africa, inland water bodies are important sources for artisanal fisheries (Andrew, Rouhani \& Seti 2000; Turpie et al. 1999). These multi-species fisheries are generally highly productive and a major contributor to the livelihoods of many local communities (Baker 2008; Neiland \& Béné 2006), especially in the large lake systems in central and eastern Africa (Heck, Béné \& Reyes-Gaskin 2007). In South Africa, however, the relative scarcity of wetlands means that those who operate artisanal fisheries, especially in floodplains, are not experienced in generating high levels of fishery productivity, with the exception of some of the larger systems such as the Phongolo floodplain (Acreman \& Hollis 1996; Merron \& Weldrick 1995; Ross \& Ross 2012).

The ecological value of the Phongolo River floodplain ecosystem, and particularly the varying natural and anthropogenic impacts on the system, have been recognised decades ago (Breen et al. 1973; Heeg \& Breen 1982). Recently, a number of additional studies were conducted on human activity in this region and the various ways in which such activities affect the ecosystem of the Phongolo floodplain (Chhotray 2010; Ellender et al. 2010; Lankford et al. 2010; Pongola River Ecosystem Services for Poverty Alleviation Report 2009). Ross and Ross (2012) found that fish was the main protein source in the floodplain area. However, whilst there seemed to be 
consensus about the importance of fishing in the region, far less is known about aspects such as the types of species most commonly consumed and the nature and extent of local trade in fish.

Given the ecological sensitivity of the Phongolo River floodplain, especially around the Ndumo Game Reserve, as well as the possible pressures that artisanal fisheries might exert on the system, this study set out to investigate artisanal fisheries in the region by focusing on fishing, fish consumption and the commercial utilisation of fish in the Ndumo area.

\section{Research method and design Study area}

The Ndumo area is situated in the north-eastern corner of South Africa's KwaZulu-Natal (KZN) province, south of Swaziland and southern Mozambique. The area is comprised of a small town (with limited facilities and infrastructure) and a number of rural villages that border the southern and western parts of the Ndumo Game Reserve. Ndumo is a provincial game reserve in South Africa that is managed by Ezemvelo KZN Wildlife. The whole area falls under the Jozini Local Municipality, which in turn forms part of the larger Umkhanyakude District Municipality in northern Maputaland (see Figure 1).

To the north of the Ndumo area, the Usutu River separates South Africa from Mozambique. In the east, the Pongola River runs through the Ndumo area from north to south and into the larger Phongolo River and its floodplain. The area lies within a summer rainfall area and has a subtropical climate with an average annual rainfall of between $670 \mathrm{~mm}$ and $1000 \mathrm{~mm}$, with temperatures ranging from $13^{\circ} \mathrm{C}$ to $40^{\circ} \mathrm{C}$ (Morgenthal et al. 2006).

\section{Design and participants}

A cross-sectional quantitative survey design (Sarantakos 2005) was adopted as a basis for this study. In total, 521 participants participated in the survey. Their average age was 37.28 years (s.d. $=13.12$ ) and participants had been living in the Ndumo area for a mean of 28.18 years (s.d. $=16.24$ ). Table 1 depicts additional demographic characteristics of the sample.

\section{Procedure and data collection}

Entry into Ndumo (i.e. various villages) was negotiated on behalf of the research team by an experienced research assistant. The research assistant also used the opportunity to gather basic data that was used as a basis for the development of a questionnaire.

Further data was collected by means of a structured questionnaire (Creswell 2007) during a second visit to the area. The questionnaire consisted of 40 questions that were divided into 4 sections: demographic characteristics; questions relating to the consumption of fish and fish products; questions relating to local fishing habits; and, finally, questions relating to local trading in fish.

A group of 16 fieldworkers were sourced from local villages and trained to recruit participants, to obtain informed consent, and to administer the questionnaire by means of structured face-to-face interviews.

All data was collected over a 5-day period in August 2013, with fieldworkers receiving a set of questionnaires in the morning, which they administered during the course of the day. Questionnaires were collected at the end of each day and scrutinised for completeness.

During the entire process of data collection, care was taken to do so in as ethical a manner as possible. Full, informed and signed consent was obtained from all participants. Participants were advised that their responses would be treated confidentially and that they had the right to withdraw from the research at any time without penalty.

\section{Data analysis and interpretation}

Data was analysed using the Statistical Package for the Social Sciences, version 21 (SPSS 21). Basic descriptive statistics (means and measures of variance) were calculated for all items in the questionnaire. Wherever relevant, findings were compared across demographic groups using chi-square tests, with cross tabulation and independent $t$-tests to verify the statistical significance of any differences that emerged, while bivariate correlations were used to examine relationships between variables (Field 2005).

\section{Results and discussion Consumers of fish}

As reflected in Table 2, fish was found to be the third most frequently consumed protein per week (after chicken and beef) among all participants. This contradicts earlier findings (Ross \& Ross 2012) that fish was the main protein source in the floodplain area. Among those who consumed fish, which included $88.9 \%$ of the participant group, fish was consumed on average twice a week. On those days that fish was consumed, participants did so 1.4 times per day on average (s.d. $=0.59)$.

Additionally, participants were asked to specify which species of fish they ate and how frequently they did so. Table 3 provides a summary of these findings.

Overall, it was found that all species of fish listed in Table 3 were consumed in fairly high numbers by a substantial portion of the participant group, with the exception of the recently introduced redclaw crayfish (Cherax quadricarinatus) (see Du Preez \& Smit 2013). Reasons for the low levels of utilisation of this (non-native invasive) species are still unclear and should be examined more closely in future studies. The two tilapia 


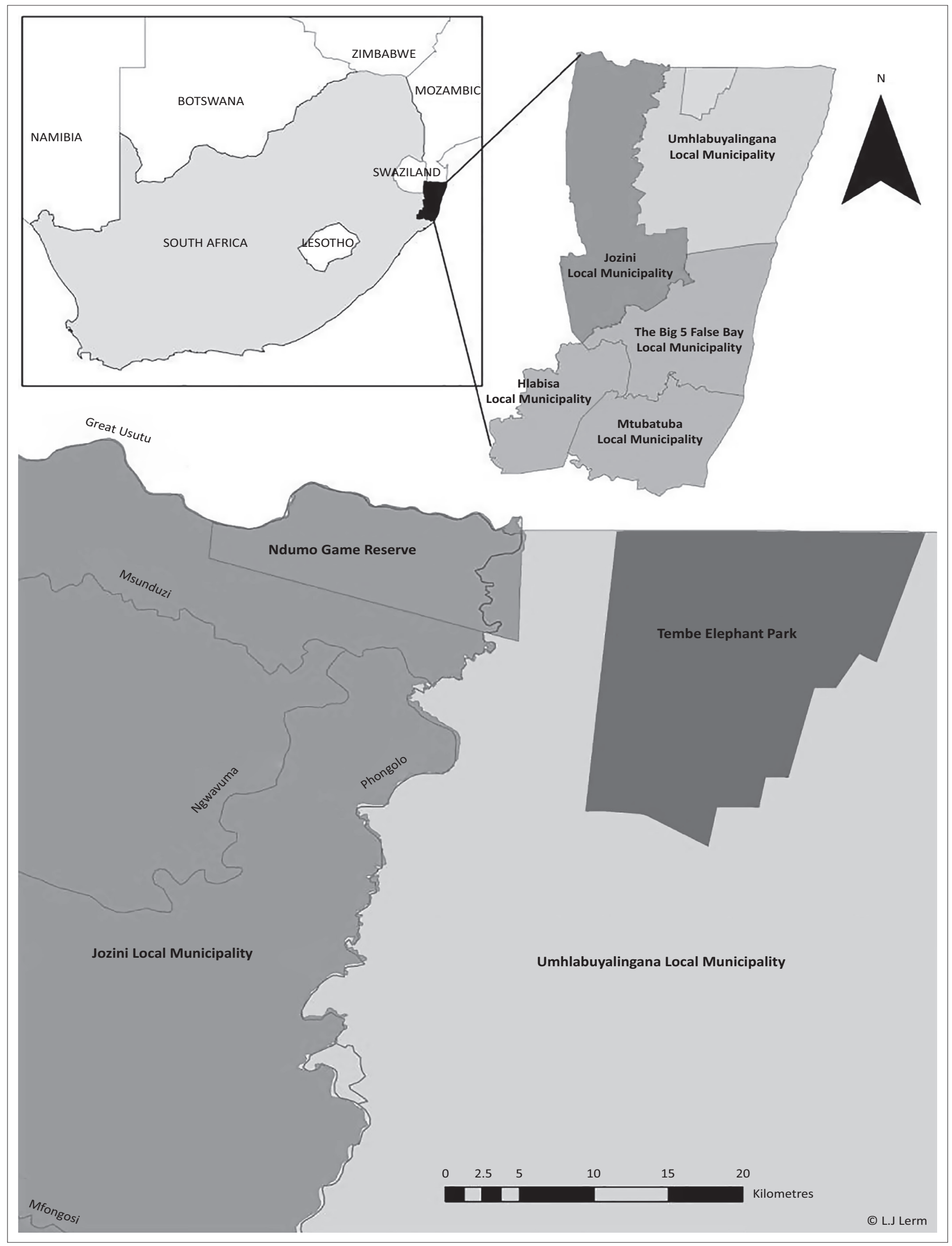

Source: Mavundza, E.J., Maharaj, R., Finnie, J.F., Kabera, G. \& Van Staden, J., 2011, 'An ethnobotanical survey of mosquito repellent plants in uMkhanyakude district, KwaZulu-Natal province, South Africa', Journal of Ethnopharmacology 137(3), 1516-1520

FIGURE 1: Location of the Ndumo area, KwaZulu-Natal, South Africa. 
species that occur in the region were the most preferred and frequently consumed species of fish, with red-breasted tilapia (Tilapia rendalli) being much more popular than Mozambique tilapia (Oreochromis mossambicus). However, while the African sharptooth catfish (Clarias gariepinus) was consumed by only $54.8 \%$ of the participants, it was the third most frequently consumed fish of all the species.

Bivariate correlations were used to examine the relationships between age, the number of years that participants resided in the Ndumo area and their consumption of fish, both generally and in relation to specific species. Age was uncorrelated to general fish consumption, but it was found that the longer participants lived in the Ndumo area, the more likely they

TABLE 1: Social and biographical characteristics of participants.

\begin{tabular}{llll}
\hline Item & Category & Frequency & $\mathbf{\%}$ \\
\hline Gender & Male & 247 & 47.8 \\
& Female & 270 & 52.2 \\
Marital status & Married & 55 & 10.9 \\
& Single (never married) & 413 & 81.8 \\
& Divorced & 11 & 2.2 \\
& Widowed & 26 & 5.1 \\
Ethnicity & African (mostly isiZulu and Tsonga) & 521 & 100 \\
\hline
\end{tabular}

TABLE 2: Mean types of protein sources consumed by villagers in the Ndumo area.

\begin{tabular}{lll}
\hline Protein source & Mean & s.d. \\
\hline Chicken & 3.91 & 1.10 \\
Beef & 3.11 & 1.13 \\
Fish & 2.70 & 1.10 \\
Goat & 1.98 & 0.79 \\
Venison (bush meat) & 1.66 & 0.98 \\
Mutton & 1.65 & 0.95 \\
Other (mainly rabbit) & 1.78 & 1.18 \\
\hline
\end{tabular}

Note: Consumption was measured on a five-point scale ranging from 'never or almost never' (1) to 'almost daily' (5)

s.d., standard deviation

TABLE 3: Percentage of participants who consumed the species as listed, and mean number of fish or crayfish consumed per week.

\begin{tabular}{|c|c|c|c|}
\hline Species & $\begin{array}{l}\% \text { of participants who } \\
\text { consumed species }\end{array}$ & $\begin{array}{l}\text { Mean number } \\
\text { consumed per week }\end{array}$ & s.d. \\
\hline Red-breasted tilapia & 89.1 & 4.17 & 3.16 \\
\hline Mozambique tilapia & 77.4 & 4.28 & 2.92 \\
\hline Brown squeaker & 64.0 & 3.15 & 3.30 \\
\hline $\begin{array}{l}\text { African sharptooth } \\
\text { catfish }\end{array}$ & 54.8 & 3.81 & 3.98 \\
\hline Silver catfish & 54.8 & 2.85 & 2.64 \\
\hline Tigerfish & 46.9 & 2.59 & 2.65 \\
\hline Redclaw crayfish & 20.9 & 2.27 & 2.10 \\
\hline
\end{tabular}

s.d., standard deviation. were to eat red-breasted tilapia (T. rendalli) $(r=0.12, p=0.02)$, brown squeaker (Synodontis zambezensis) $(r=0.15, p=0.02)$, Mozambique tilapia (O. mossambicus) $(r=0.13, p=0.02)$ and, in particular, tigerfish (Hydrocynus vittatus) $(r=0.24, p=$ $0.00)$, suggesting that those living in this region develop an acquired taste for these species.

Asked how they obtained the fish they consumed, $46.1 \%$ of participants $(54.4 \%$ of females and $37.3 \%$ of males) indicated that they bought the fish from a vendor in the area; $37.8 \%$ (similar for both genders) obtained the fish from family or friends, whereas $16.1 \%$ (25.5\% of males and $7.2 \%$ of females) caught the fish themselves. A chi-square test with cross tabulation confirmed that the association between gender and where participants obtained the fish was significant $\left[\chi^{2}(2, N=457)=31.18, p=0.00\right]$ and of moderate strength $(\phi=0.26)$.

\section{Local fishermen and fisherwomen}

Participants indicated that they commonly fished in an average of 4.32 (s.d. $=5.07$ ) different locations. However, the majority of participants $(70.48 \%)$ only fished in one to three locations. Among these sites, $81.02 \%$ of fish was caught in rivers and streams, $13.60 \%$ in pans and $1.9 \%$ in other (unspecified) locations, suggesting that fishing was mostly focused around the river system and that pans were not highly exploited for fishing. The main reason for this seems to be that the majority of the pans in the Ndumo region falls within the confines of the Ndumo Game Reserve and, as such, are protected.

Participants indicated that the bulk of fish caught was intended to be sold (54.73\%) and that $44.28 \%$ of fish caught was for personal consumption.

The most commonly employed fishing techniques were handlines $(26.77 \%)$, traditional baskets $(25.81 \%)$ and drag nets $(22.26 \%)$, followed by gill nets $(17.10 \%)$ and, to a much lesser extent, fishing rods $(8.19 \%)$. Thus, non-commercial techniques were used and no evidence of large-scale fishing was uncovered. This indicates that local communities in the area fish primarily for personal subsistence use rather than for large-scale commercial reasons.

The species of fish that participants usually caught and the average number of fish per species is summarised in Table 4.

TABLE 4: Summary of type of species caught, and number of each species caught in an average week.

\begin{tabular}{|c|c|c|c|}
\hline Species & $\begin{array}{l}\text { Percentage of participants who } \\
\text { actively caught this species }\end{array}$ & $\begin{array}{l}\text { Mean number of species } \\
\text { caught in a typical week }\end{array}$ & s.d. \\
\hline Red-breasted tilapia & 97.1 & 23.86 & 33.83 \\
\hline Mozambique tilapia & 85.5 & 14.71 & 16.62 \\
\hline Brown squeaker & 78.9 & 19.22 & 27.19 \\
\hline African sharptooth catfish & 73.7 & 16.51 & 25.21 \\
\hline Silver catfish & 72.9 & 12.24 & 15.31 \\
\hline Tiger fish & 59.0 & 11.11 & 14.93 \\
\hline Redclaw crayfish & 31.8 & 6.92 & 8.70 \\
\hline
\end{tabular}

s.d., standard deviation. 
TABLE 5: Number of fish sold during a typical week, and mean and modal prices per average-sized specimen for each species (2013 data).

\begin{tabular}{llll}
\hline Species & Mean number sold per week & Mean price per fish & Modal price per fish (in ZAR) \\
\hline Red-breasted tilapia & 29.02 & 20.30 & 10 \\
Mozambique tilapia & 28.87 & 18.75 & 10 \\
Brown squeaker & 20.05 & 23.88 & 20 \\
African sharptooth catfish & 18.02 & 13.85 & 10 \\
Silver catfish & 17.84 & 13.87 & 10 \\
Tiger fish & 15.64 & 14.03 & 10 \\
Redclaw crayfish & 13.92 & 16.76 & 15 \\
\hline
\end{tabular}

ZAR, South African rand.

Red-breasted tilapia and, to a lesser degree, Mozambique tilapia emerged as the species that were most frequently caught in the region. Whilst the vast majority of participants indicated that they actively sought to catch African sharptooth catfish, a much lower number of these fish was caught. However, as can be seen from the large standard deviations associated with the number of fish caught, great variability exists in this regard, with some fishermen and -women catching 1 or 2 fish per week and 1 individual reporting catching as many as 200 tilapia species per week.

These differences could possibly be attributed to the fact that whereas most fishermen and -women fished for personal consumption and as such only needed a relatively small number of fish, a few residents did so for small-scale commercial purposes and therefore made far larger catches. No statistically significant gender differences were found in relation to the types or numbers of fish species caught.

In order to determine whether any changes or trends pertaining to fish populations had been observed by local fishermen and -women, participants were asked whether they had noticed any changes in the number of fish over the past 10 years. Responses were measured on a five-point scale ranging from 'decreased a lot' (1) to 'increased a lot' (5). A score of 3 indicated that there was no observed change. Participants' mean score was 2.91 (s.d. = 1.22), suggesting that they observed very little change. The same was true for the average size of the fish, which was viewed as decreasing only fractionally $(\mathrm{M}=2.89 ; \mathrm{s} . \mathrm{d} .=1.25)$.

\section{Fish traders}

Lastly, data were also collected from participants who sold fish, but did not catch it themselves. The average trader indicated that he or she had been selling fish in the area for 7.50 years (s.d. $=5.87$ ) and that they obtained $85 \%$ of the fish from local fishermen and -women and 15\% from other undisclosed suppliers.

Traders indicated that they mostly sold their fish in nearby towns $(40.7 \%)$ (mainly Ndumo, but occasionally Jozini, approximately $75 \mathrm{~km}$ farther south) and in their own villages (30.7\%). To a lesser extent, fish was also sold in other villages where they did not reside $(15.9 \%)$ or 'next to the road' (referring to areas outside towns or villages) (11.1\%). This suggests that the local fishing industry, though limited in opportunities, contributes directly and meaningfully to the economy of the Ndumo area, in which income-generating opportunities are very scarce (Ogilvie pers. comm. 2014).

Table 4 indicates the number of fish that were sold by traders during the course of a typical week. It also reflects the mean and modal prices (in South African rand [ZAR]) that is charged for an average-sized fish of a given species.

The findings reported in Table 5 suggest that the two species of tilapia and African sharptooth catfish were the two species most frequently sold and also the most expensive of all the fish species that were exploited in the area. However, when the modal prices for all the fish species were considered, it would appear that fish of all species were most commonly sold for ZAR 10 (with the exception of African sharptooth catfish, which sold for a modal amount of ZAR 20; and the redclaw crayfish, which sold for a modal amount of ZAR 15). As such, these species likely play an important role in the context of the local economy within the Ndumo and the greater Phongolo River floodplain region.

None of these species are regarded as threatened or endangered, with the exception of the tigerfish, which is a protected species in South Africa. However, even though residents tend to increase their consumption of this species the longer they reside in the Ndumo area, this species is consumed fairly infrequently and does not appear to be specifically targeted as much as being incidentally caught.

Assessing the impact of human activities on fish populations in the Ndumo area is hampered by the fact that very little research has been conducted to determine the size and reproductive rate of fish populations in this ecologically sensitive region (Smit pers. comm. 2014). As such, it is hoped that the findings of the present study would provide the necessary baseline data on fish consumption in the region so that the ecological impact on local fish populations can be assessed once future studies on fish populations and reproductive rates in the area have been completed.

\section{Conclusion}

The results of this study suggest that artisanal fishery activities in the Ndumo area of KZN play an important role in supporting the livelihood of members of this community, both by serving as an important form of sustenance and by constituting an important economic resource. However, given the ecological sensitivity of the floodplain, it is also 
necessary to assess the impact that these interactions might have on the fish populations in the region, for example, by determining the size and reproductive rate of the most important species and populations. To fully understand human habits and needs in the floodplain, the value of extended socio-economic research in the future in this region should also be seriously considered. Finally, continuous monitoring of artisanal fishery activities is important to assess and ensure the sustainability of these interactions in the region.

\section{Acknowledgements}

The authors would like to thank the Water Research Commission (WRC) of South Africa (Project K5-2185 N.J. Smit, PI) for the financial support of this study. Views expressed are those of the authors and not those of the WRC.

\section{Competing interests}

The authors declare that they have no financial or personal relationships which may have inappropriately influenced them in writing this article.

\section{Authors' contributions}

E.v.E. (North-West University) was the project leader. All four authors were involved in the conceptualization of the research. H.C.C. (North-West University) and W.N. (NorthWest University) were responsible for all data collection and analysis. All authors provided inputs and helped in the writing of the article.

\section{References}

Acreman, M.C. \& Hollis, G.E., 1996, Water Management and Wetlands in subSaharan Africa, International Union for the Conservation of Nature (IUCN), Gland, Switzerland.

Andrew, T.G., Rouhani, Q.A. \& Seti, S.J., 2000, 'Can small-scale fisheries contribute to poverty alleviation in traditionally non-fishing communities in South Africa?', African Journal of Aquatic Science 25(1), 49-55. http://dx.doi. org/10.2989/160859100780177938

Baker, C.F., 2008, 'Seasonal Floodplain Wetlands as Fish Habitat in Oregon and Washington', PhD thesis, Department of Fisheries Science, Oregon State University, Corvallis.
Béné, C., Macfadyen, G. \& Allison, E.H., 2007, 'Increasing the contribution of small-scale fisheries to poverty alleviation and food security', p. 125, Food and Agriculture Organization of the United Nations (FAO) Fisheries Technical Paper No. A8riculture Rome.

Breen, C.M., Furness, H.D., Heeg, J. \& Kok, J. (eds.), 1973, 'Bathymetric studies on the Pongola River floodplain', Journal of the Limnological Society of Southern Africa 4(2), 95-100. http://dx.doi.org/10.1080/03779688.1978.9633158

Chhotray, V., 2010, 'The impacts of the ecosystem service and environmental governance on human well-being in the Pongola region, South Africa', Working paper, UEA, Norwich and Institute for Natural Resources, Pietermaritzburg. https://ueaeprints.uea.ac.uk/37820/

Creswell, J.W., 2007, Qualitative Inquiry and Research Design: Choosing Among Five Approaches, Sage Publications, Thousand Oaks, California.

Du Preez, L.H. \& Smit, N.J., 2013, 'Double blow: Alien crayfish infected with invasive temnocephalan in South African waters', South African Journal of Science 109(9/10), 1-4. http://dx.doi.org/10.1590/sajs.2013/20130109

Ellender, B.R., Weyl, O.L.F, Winkler, H. Stelzhammer, H. \& Traas, G.R.L., 2010 'Estimating angling effort and participation in a multi-user, inland fishery in South Africa', Fisheries Management and Ecology 17, 19-27. http://dx.doi.org/10.1111/ j.1365-2400.2009.00708.x

Field, A., 2013, Discovering Statistics using IBM SPSS Statistics, 4th edn., Sage Publications, London.

Heck, S., Béné, C. \& Reyes-Gaskin, R., 2007, 'Investing in African fisheries: Building links to the Millennium Development Goals', Fish and Fisheries 8(3), 211-226. http://dx.doi.org/10.1111/j.1467-2679.2007.00251.x

Heeg, J. \& Breen, C.M., 1982, 'Man and the Pongola Floodplain', Report No. 56 of the Committee for Inland Water Ecosystems, National Programme for Environmental Sciences, Council for Scientific and Industrial Research (CSIR), South Africa. https://ueaeprints.uea.ac.uk/33628/

Lankford, B., Pringle, C., Dickens, C., Chhotray, V., Mander, M., Goulden, M. et al., 2010, 'The impacts of ecosystem services and environmental governance on human well-being in the Pongola region, South Africa', Working Paper, University of East Anglia and Institute of Natural Resources, Norwich, UK and Pietermaritzburg, South Africa.

Mavundza, E.J., Maharaj, R., Finnie, J.F., Kabera, G. \& Van Staden, J., 2011, 'An ethnobotanical survey of mosquito repellent plants in uMkhanyakude district, KwaZulu-Natal province, South Africa', Journal of Ethnopharmacology 137(3), 1516-1520. http://dx.doi.org/10.1016/j.jep.2011.08.040

Merron, G.S. \& Weldrick, S.K., 1995, Fisheries management of the Phongola River floodplain, Investigational Report No. 51, JLB Smith Institute of Ichthyology, Grahamstown, South Africa.

Morgenthal, T.L., Kellner, K., Van Rensburg, L., Newby, T.S. \& Van der Merwe, J.P.A 2006, 'Vegetation and habitat types of the Umkhanyakude Node', South African Journal of Botany 72, 1-10. http://dx.doi.org/10.1016/j.sajb.2005.03.003

Neiland, A.E. \& Béné, C., 2006, Tropical river fisheries valuation: A global synthesis and critical review, International Water Management Institute, Colombo, Sri Lanka.

Pongola River Ecosystem Services for Poverty Alleviation (PRESPA), 2009, 'Livelihoods and poverty linkages to the ecosystem services provided by the Pongola Floodplain', Project Brief No. 3. https://www.uea.ac.uk/polopoly fs/1.140758!Livelihoods\%20project\%20brief\%20PRESPA\%20Dec\%2009..pdf

Ross, M. \& Ross, T., 2012, Umkhanyakude District Municipality, Status Quo Report: Rivers \& Wetlands, Environmental Management Framework Report, Johannesburg.

Sarantakos, S., 2005, Social Research, 3rd edn., Palgrave Macmillan.

Turpie, J., Smith, B., Emerton, L. \& Barnes, J., 1999, Economic value of the Zambezi Basin Wetlands, Zambezi Basin Wetlands Conservation and Resource Utilization Project, International Union for the Conservation of Nature (IUCN), Regional Office for Southern Africa, Harare. 